\title{
PWM Soft-Switched Converters With A Single Active Switch
}

\author{
Lúcio R. Barbosa, Ernane A. A. Coelho, João B. Vieira Jr., Luiz C. de Freitas, \\ Valdeir J. Farias, Non-members (Universidade Federal de Uberlândia)
}

\begin{abstract}
This paper presents several converters which, having only a single active switch, are able to operate with PWM characteristics in a soft switching way. In addition such converters can work in high switching frequencies for wide load range without great limitations. In order to illustrate the operating principles of these converters a detailed analysis, including simulations and experimental tests are carried out. The validity of these converters is assured by the obtained results.
\end{abstract}

Key words: dc-dc converters, soft switching, PWM, single active switch.

\section{Introduction}

High switching frequencies are necessary to reduce the size and the weight of the DC-DC converters. However, this yields high switching losses and, consequently, low efficiency in hard switching converters.

To reduce the switching losses, initially, risen the snubbers. Examples of these snubbers can be found in the references [1], [2], [3] and [4].

Before the study of such snubbers had been completed, the QRCs (Quasi Resonant Converters) were proposed in [5], changing the research trends to this area. These converters present some disadvantages such as load limitations high stresses of voltage and current and control problems due to frequency variations.

After, the QRC-PWM converters were proposed in [7]. These converters do not have control problems but they contain all the others disadvantages of the QRC.

Nowadays there are modern converters which presents less problems than the previous converters. Examples of such converters can be found in the references [6] and [10]. Although the converters from reference [10] present several advantages they can not operate in soft switching way with duty cycle less than half. The converter from reference [6] contains several advantages too, but its main switch turns off hard and has high current stresses.

The converter described in [8] is the results of researches to find a converter which did not present the problems described before. Although this converter has several advantages, it is not perfect and contains two active switches like the most part of the PWM soft-switching converters existent until 1995 when, after lots of researches, it was found the converter described in [9]. This converter using a commutation cell with just a single active switch is able to operate with the characteristics of the conventional PWM converters with soft switching in high frequencies for a wide load range without great limitations.

This paper is an extension of [9], in which beyond a review of that converter, it will be analyzed its operation limits and a derived converter family

\section{Operating principles of the Buck converter}

Fig. 1 shows the circuit diagram of the Buck PWM SoftSingle Switched converter (PWM-SSSC). To emphasize the operating principles of this converter, its working cycle is divided in 8 stages which are shown in fig. 2 and described as follows.

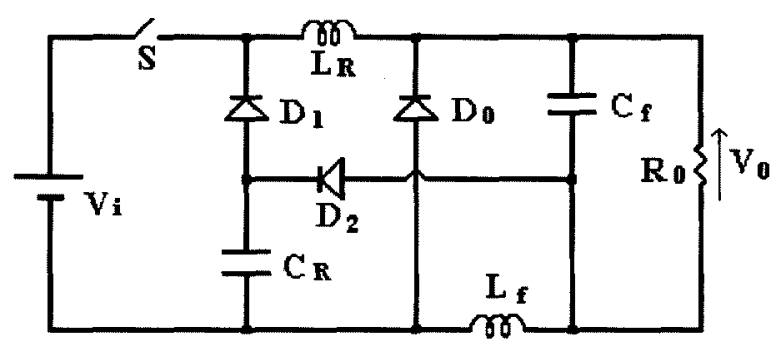

Fig. 1 - Circuit diagram of the Buck PWM-SSSC

1st stage [ $\left.t_{0} t_{1}\right]$ : The first stage begins when switch $S$ turns on in a ZCS way. In this stage, the current through resonant inductor $L_{R}$ increases linearly until it becomes equal to load current at time $t_{1}$ (fig. 3 ).

2nd stage $\left[t_{1}, t_{2}\right]:$ At $t_{1}$, the resonant stage begins. In this time interval, current $I_{L R}$ rises while $V_{C R}$ goes from $\left(-V_{0}\right)$ to $\left(V_{i}-V_{0}\right)$, than it decreases until the value of the capacitor voltage becomes $V_{i}$. When diode $D_{1}$ turns on at time $t_{2}$, the capacitor voltage is clamped, ending the resonant period

3rd stage $\left[\mathrm{t}_{2}, \mathrm{t}_{3}\right]:$ In this time interval, the current through the inductor $L_{R}$ decreases linearly until it becomes equal to load current. During this period, the voltage across the inductor $L_{R}$ is $V_{0}$ and across the capacitor it remains $V_{i}$ 

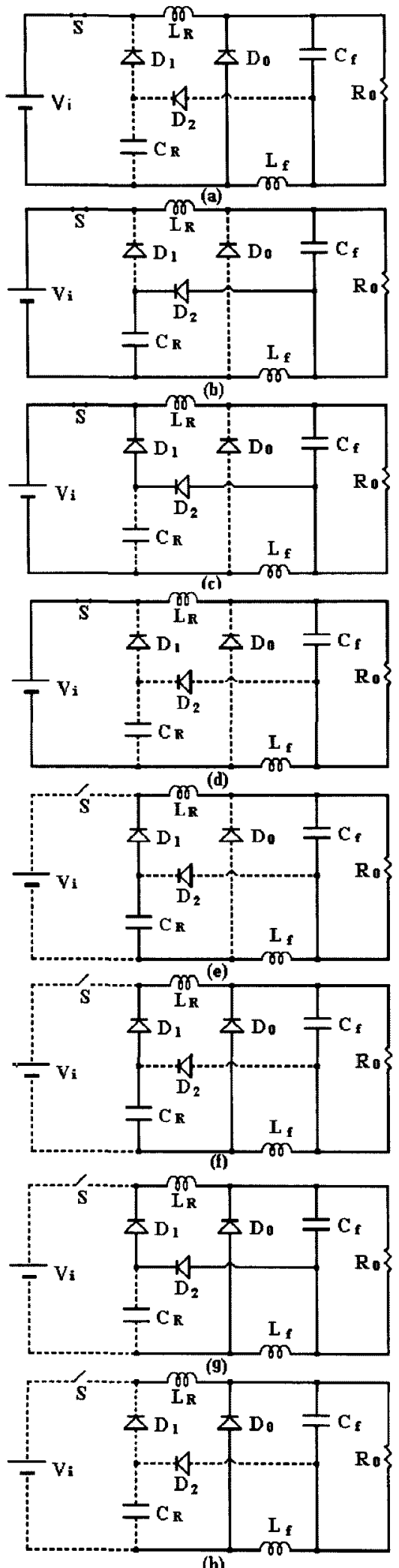

(h)

Fig. 2 - Equivalent circuit for each operation stage of the Buck PWM-SSS converter 4th stage $\left[t_{3}, t_{4}\right]:$ During this stage, only switch $S$ and inductor $L_{R}$ are conducting and energy transference from source to load occurs in a time interval defined by duty cycle.

5th stage $\left[t_{4}, t_{5}\right]:$ This stage begins when switch $S$ turns off. This happens in a soft switching way, since the voltage across the capacitor $C_{R}$ is equal to $V_{i}$, producing a ZVS switching. In this time interval, the capacitor discharges linearly until its voltage reaches zero, so diode $\mathrm{D}_{2}$ turns on.

6th stage [ $\left.t_{5}, t_{6}\right]:$ In this time interval, there is a new resonance between capacitor $C_{R}$ and inductor $L_{R}$. During this stage, the capacitor charges with negative voltage while the current through inductor falls. This happens until voltage $V_{C R}$ becomes $\left(-V_{0}\right)$ at time $t_{6}$.

7th stage $\left[t_{6}, t_{2}\right]:$ When diode $D_{2}$ turns on, the inductor $L_{R}$ current decreases linearly to zero by load voltage action. After inductor current reaches zero, switch $S$ will can be turned on in a ZCS way.

8th stage $\left[t_{7}, t_{8}\right]:$ In this stage, only diode $\mathrm{D}_{0}$ conducts the load current. The duration of this stage is defined by switch modulation. At the end of this time interval, switch $\mathrm{S}$ turns on and the next operating cycle begins.

The main theoretical waveforms are shown in Fig. 3.

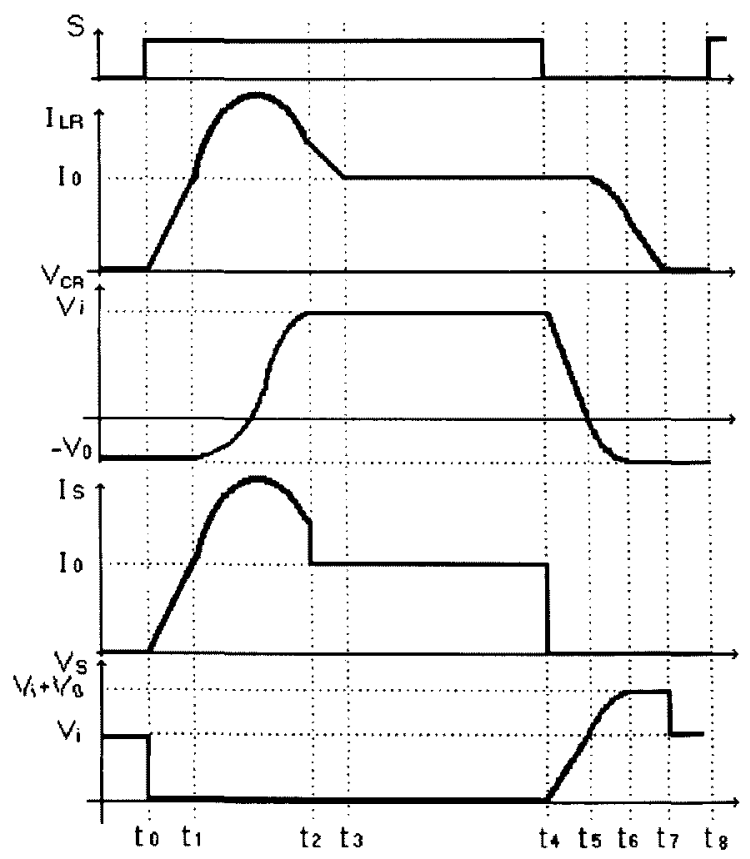

Fig. 3 - Theoretical waveforms of the Buck converter

According to the operation principles described above, some important characteristics of this converter can be related as follows. 
As it can be seen, this converter, having only one active switch, operates with PWM characteristics in a soft switching way. This is the main advantage of this converter.

To make possible this converter without auxiliary switch, it is necessary to obtain a potential less than the source negative potential. This is carried out by putting the filter inductor on the negative side of the load instead of the positive side. Therefore when diode $D_{0}$ is on, the node between filter capacitor and filter inductor has a potential $\left(-V_{0}\right)$. This clamps capacitor voltage $V_{C R}$ in $\left(-V_{0}\right)$ at the end of the resonant period (sixth stage), thus the current in resonant inductor decreases until it reaches zero, producing favorable conditions for the turning on of switch S.

\section{Voltage gain}

To determine the voltage gain of the Buck converter, several equations were written based on the following assumptions:

- Supply voltage $V_{i}$ and load current $I_{0}$ are ripple-free.

- All components and switches are ideal.

Furthermore, the following definitions were used.

$\omega_{0}=\sqrt{\frac{1}{\mathrm{C}_{\mathrm{R}} \mathrm{L}_{\mathrm{R}}}}$

$\alpha=\frac{I_{0}}{V_{i}} \sqrt{\frac{L_{R}}{C_{R}}}$

$\mathrm{k}_{1}=\frac{\mathrm{V}_{0}}{\mathrm{~V}_{\mathrm{i}}}$

The final result, was the voltage gain given by the following equation:

$$
\frac{V_{0}}{V_{i}}=D_{1}+\frac{1}{T \omega_{0}}\left(-\alpha+\frac{1}{2 \alpha}\right)
$$

Where:

$D_{1}=\frac{\left(t_{4}-t_{0}\right)}{T}$

Although, it was not emphasized before, but the operation principles described until now are true only if $\alpha$ is greater than $\mathbf{k}_{\mathbf{1}}\left(\boldsymbol{\alpha}>\mathbf{k}_{\mathbf{1}}\right)$.

This situation is represented by area 1 in Fig. 4 . In this conditions $V_{C R}$ reaches $\left(-V_{0}\right)$ in the sixth stage, establishing favorable conditions for switch $S$ to turn off soft, since capacitor $C_{R}$ voltage will reach $V_{i}$ in the second stage in next operation cycle.
Area 2 in Fig. 4 represents the condition in which ( $2 \mathrm{k}_{1}$ 1) $<\alpha<k_{1}$. In that situation $I_{L R}$ becomes zero in the sixth stage, preventing $V_{C R}$ to reach $\left(-V_{0}\right)$. Despite that the capacitor $C_{R}$ voltage will be $V_{i}$ in the end of next second stage, furnishing soft turning off to the active switch.

Switch $S$ turns off hard in all conditions $\left(\alpha<2 \mathrm{k}_{1}-1\right)$ represented by area 3 of Fig. 4 since $V_{C R}$ do not reach $V_{i}$ in the second stage in such situation.

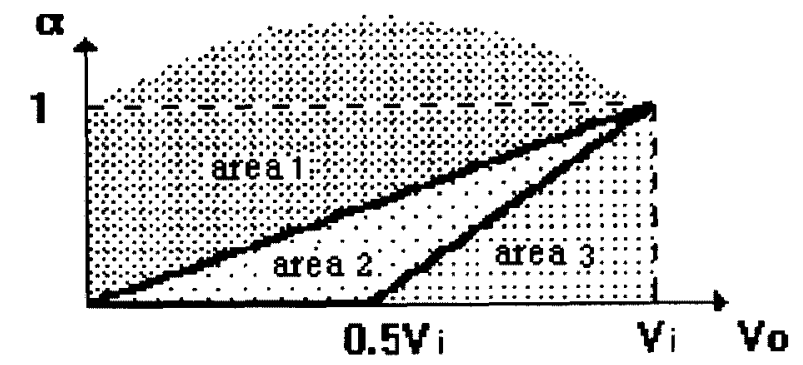

Fig. 4 - Operation conditions of the Buck converter

Using a similar procedure to obtain the equation (4), it was developed voltage gain expressions for the three previous conditions and their graphic representation is shown in Fig. 5. It can be seen that the converter operates almost like the conventional PWM in the conditions represented by area 1 .

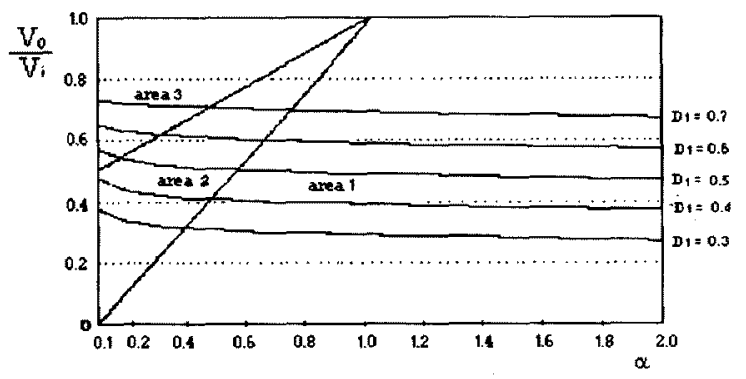

Fig. 5 - Voltage gain of the Buck converter

\section{A family of converters with just a single active switch}

As it can be seen, the Buck PWM-SSS converter shown in fig. 1 is composed of the conventional Buck PWM converter added by the resonant network which contains a diode connected in a node which is not the reference node of the supply voltage but it is the common node between the two filter elements which are in parallel with diode $D_{0}$.

Although the other converters of the family which is being proposed are obtained in a similar way, the obtaining process presents some difficulties since such node is not available in the Boost, Buck-Boost and SEPIC converters, which do not have an output filter inductor. To overcome this problem, an auxiliary filter composed by inductor La and capacitor $\mathrm{Ca}$ can be used in parallel with diode $\mathrm{D}_{0}$ as shown in Fig. 6. This auxiliary filter do not produce any important alteration in the basic operation of these converters. 


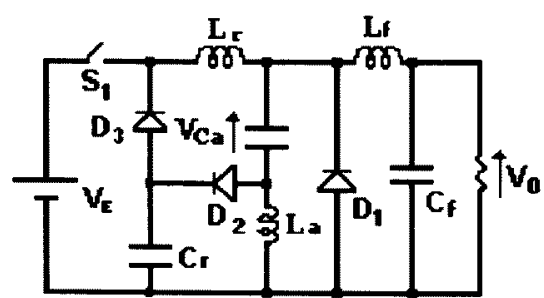

(a)

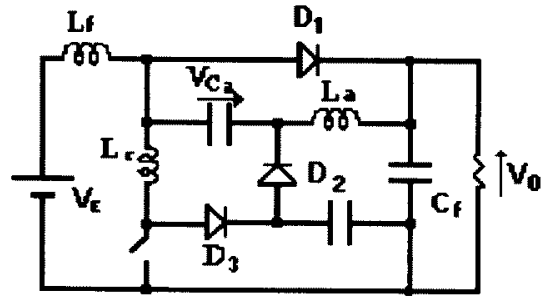

(b)

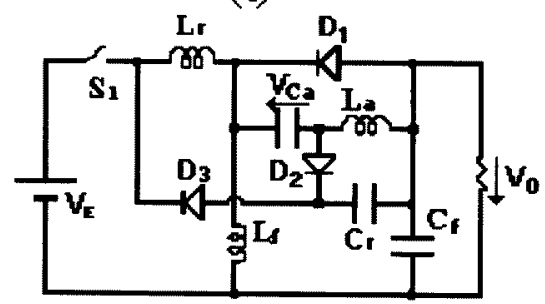

(c)

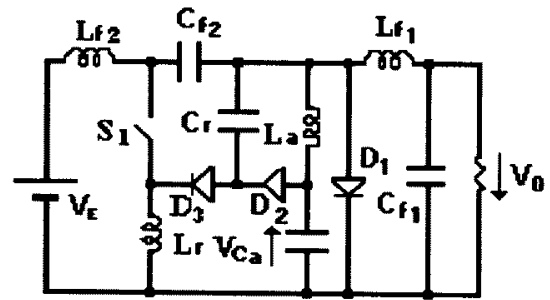

(d)

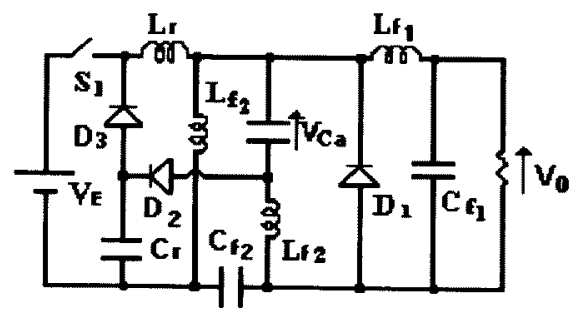

(e)

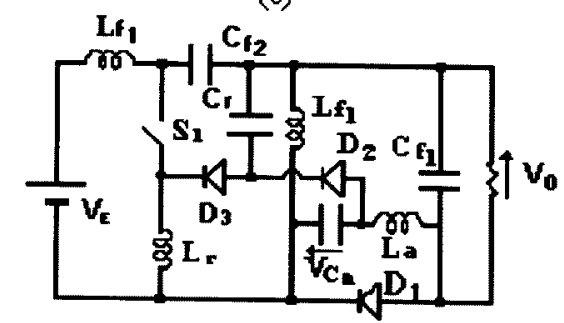

(f)

Fig. 6 - A family of PWM SSS converter.(a)Buck (b)Boost (c) Cuk (d) Buck-Boost (e)SEPIC (f)ZETA
Since the Cuk and ZETA converters have an adequate node to connect the diode $D_{2}$, as it was seen before for the Buck converter, they do not require the auxiliary filter and their basic configurations can be seen through Fig. 7 .

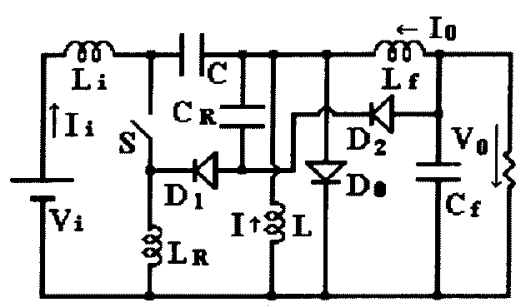

(a)

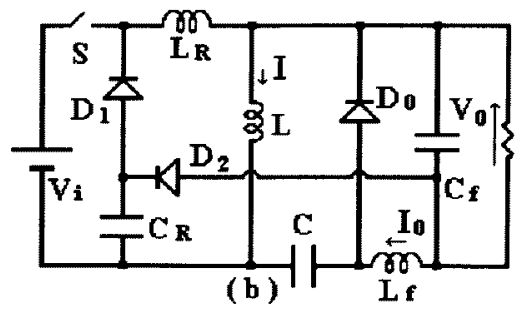

Fig. 7 - Cuk and ZETA PWM SSS converters without auxiliary filter (a) Cuk (b) ZETA.

The normalized phase diagram of all converters of this family can be represented by a single diagram as shown in Fig. 8. Although the phase diagram of each one of these converters shapes like that, the values of $I_{x}, I_{b}, V a$ and $V_{b}$ are different for all converters as shown in tab. 1 .

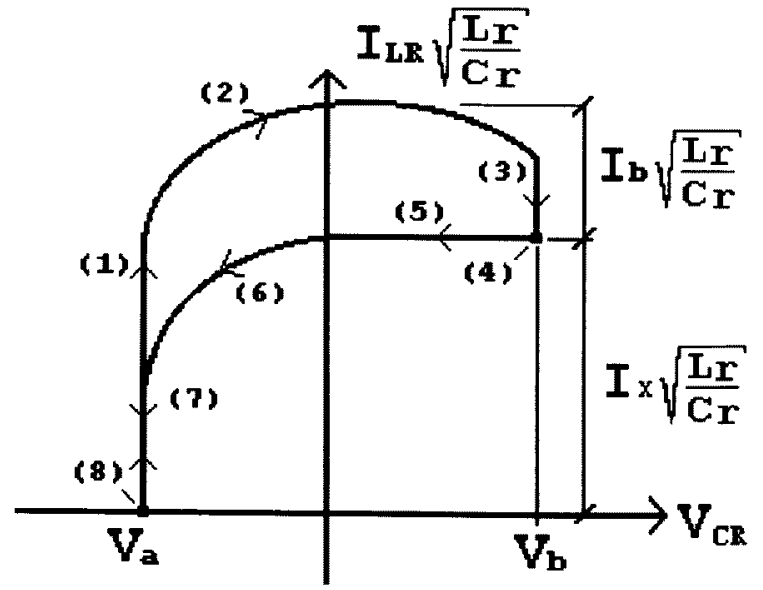

Fig. 8 - Normalized phase diagram of PWM SSS converter.

Tab. 1: Values of parameter shown in fig. 6

\begin{tabular}{|c|c|c|c|c|}
\hline CONV. & $\left(\mathbf{I}_{x}\right)$ & $\left(\mathrm{I}_{\mathrm{b}}\right) \sqrt{L_{R} / C_{R}}$ & Va & $\mathrm{V}_{\mathrm{b}}$ \\
\hline Buck & Io-Ia & $\mathrm{Vi}$ & $-V_{0}$ & $\mathrm{Vi}$ \\
\hline Boost & li-la & Vo & $-2 \mathrm{Vo}+\mathrm{Vi}$ & 0 \\
\hline Cuk & $\mathrm{Ii}+\mathrm{Io}-\mathrm{Ia}$ & $\mathrm{Vi}+\mathrm{Vo}_{\mathrm{O}}$ & $-V_{0}$ & $\mathrm{Vi}+\mathrm{Vo}_{0}$ \\
\hline Buck-Bo & (I-Ia) & $\mathrm{Vi}+\mathrm{Vo}_{0}$ & -Vo & $\mathrm{Vi}+\mathrm{Vo}$ \\
\hline SEPIC & $\mathrm{Ii}+\mathrm{I}-\mathrm{Ia}$ & $\mathrm{Vit} \mathrm{Vo}$ & $-2 \mathrm{Vo}$ & $\mathrm{Vi}$ \\
\hline ZETA & Io+I-Ia & $\mathrm{Vi}+\mathrm{Vo}_{\mathrm{O}}$ & $-2 \mathrm{Vo}$ & $\mathrm{Vi}$ \\
\hline
\end{tabular}




\section{Simulation and experimental results for the Buck} converter

For additional illustration, the Buck PWM-SSS converter was studied by simulation, where the following parameter set was used:

$\mathrm{V}_{\mathrm{i}}=100[\mathrm{~V}] ; \mathrm{L}_{\mathrm{R}}=5.0[\mu \mathrm{H}] ; \mathrm{F}_{\mathrm{S}}=200[\mathrm{kHz}] ; \mathrm{C}_{\mathrm{R}}=6.8[\mathrm{nF}] ;$ $\mathrm{R}=17.0[\Omega] ; \quad \mathrm{Lf}=162[\mu \mathrm{H}], \mathrm{C}_{\mathrm{f}}=660[\mu \mathrm{F}] \quad \mathrm{D}=0.5$

Fig. 9 shows the waveforms obtained by this simulations. It can be seen from this figure, this converter really operates in a soft switching way.

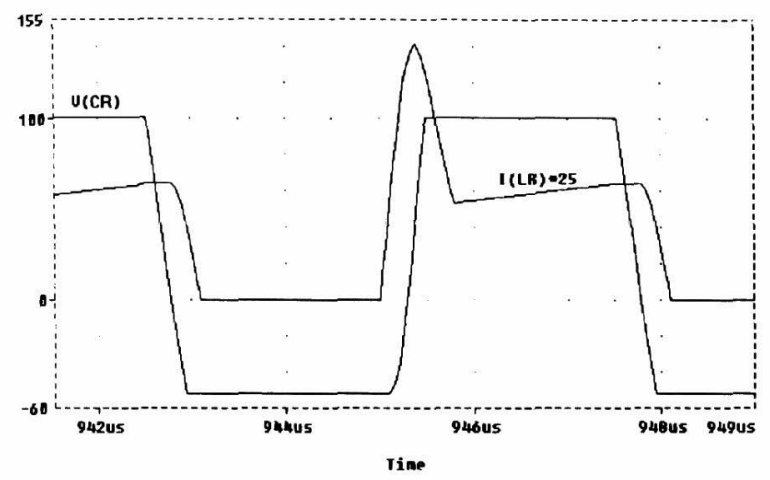

(a)

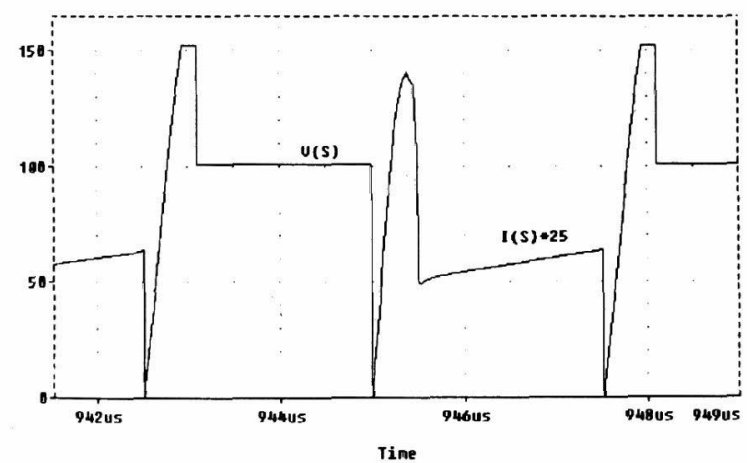

(b)

Fig. 9 - Simulation waveforms of the Buck converter

A circuit prototype was constructed to verify the theoretical waveforms. The parameters values used in the experimental circuit are the same specified for simulation. The active switch used was the MOSFET IRF640 and the diodes were the MUR850.

Fig. 10 shows the most relevant experimental waveforms obtained.

It can be seen from this figure that the converter operates in a soft switching way, as it was expected.

Fig. 11 shows the efficiency obtained for the Buck converter implemented in laboratory. The curve 1 was obtained by using of commutation cell and curve 2 was obtained with converter operating in a hard way. It can be seen the commutation cell provokes an increment around $2 \%$ in the converter efficiency for the rated load condition.
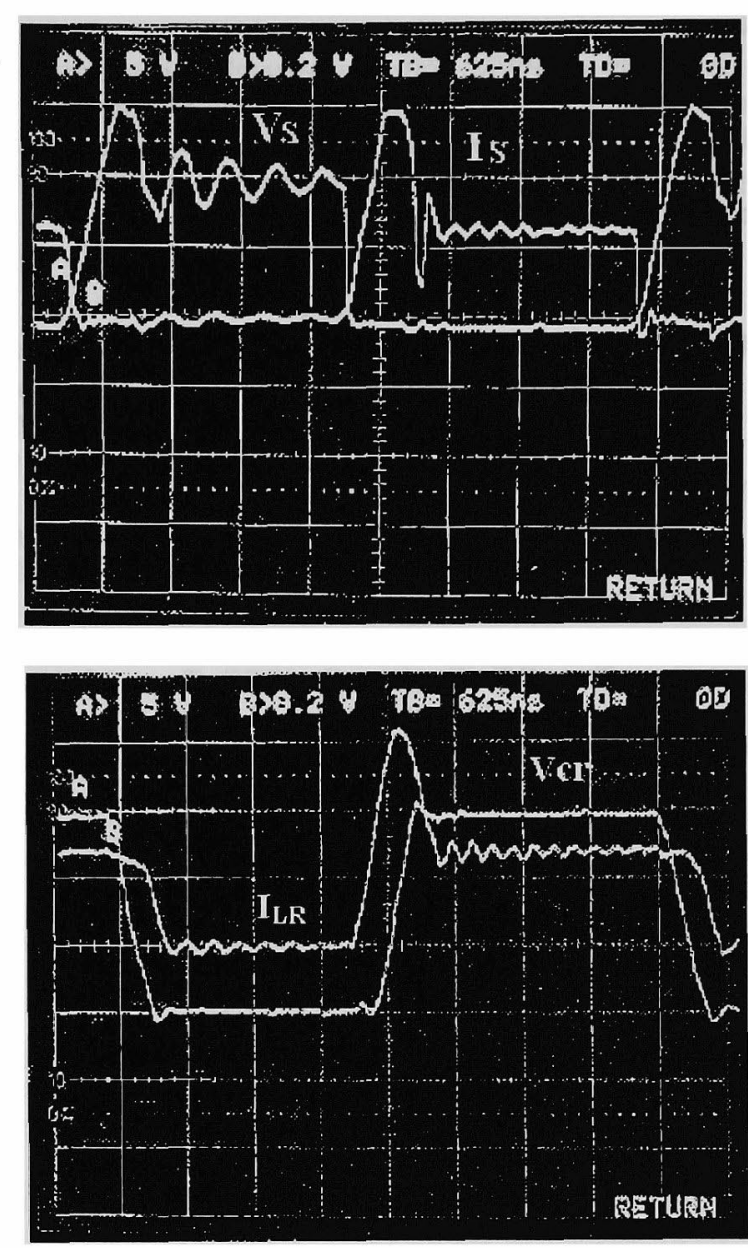

Fig. 10 - experimental waveforms Time: $0.625 \mu \mathrm{s} / \mathrm{div}$; voltage: $50 \mathrm{~V} /$ div.; Is :2 A/div.; ILR: $2 \mathrm{~A} / \mathrm{div}$.

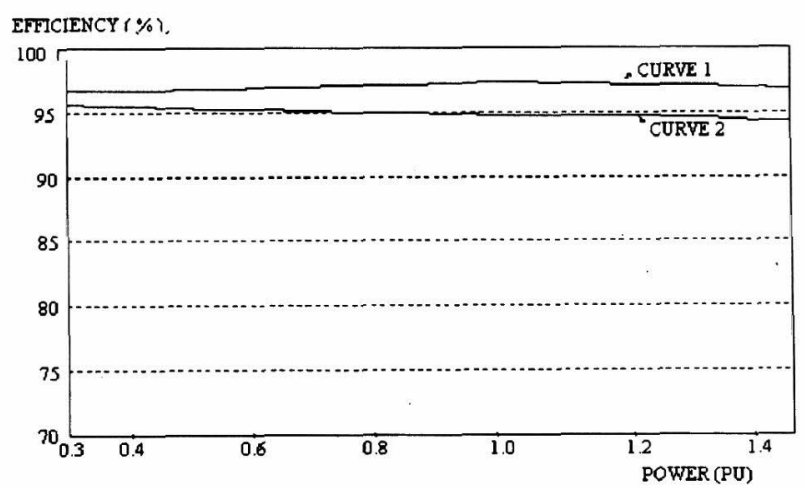

Fig. 11 - Efficiency of the Buck converter

Based on these results we can conclude that the performance of this converter is satisfactory over several aspects, in spite of load limitation in high duty cycle (greater than half) and the necessity to put an impedance between the GND potential of the input source and the GND potential of the load. 


\section{Conclusion}

A family of PWM soft-single-switched converter has been presented. Despite of the limitations described before these converters have good performance since it can operate with soft-switching in high frequency for a wide load range with PWM characteristics.

(Manuscript received Aug. 16, '96 revised April 21, '97)

\section{References}

[1] E. T. Calkin and B.H. Hamilton, "Circuit techniques for improving the switching loci of transistor switches in switching regulators", IEEE Trans. Industry Applications v. IA-12(4), 364-369, July/August 1976.

[2] W. McMurray, "Selection of Snubbers and Clamps to Optimize the Design of Transistor Switching Converters", IEEE Trans. Industry Applications 16 (4): 513-523, July/August 1980.

[3] Hiromichi Ohashi, "Snubber Circuit for High-Power Gate Turn-Off Thyristors", IEEE Trans. Industry Applications vol.Ia-19, n²4, July/August 1983.

[4] J. C. Bendien, H. van der Broeck and G. Fregien, "Recovery Circuit for Snubber Energy in Power Electronics Applications with High Switching Frequencies", IEEE Trans. Power Electronics 3 (1): 26-30, January 1988.

[5] Fred C. Lee, "High Frequency Quasi-Resonant Converter Technologies", IEEE Trans. Power Electronics 3, vol. 76 N. 4, April 1988.

[6] G. Hua, C. S. Leu, F.C. Lee. "Novel Zero-Voltage Transition PWM Converters". IEEE-PESC'92, p.55-61

[7] Ivo Barbi, J. C. Bolacel, D. C. Martins, F. B. Libano, "Buck Quasi-Resonant Converter Operating at Constant Frequency: Analysis, Design and Experimentation", IEEE PESC.'89, pp. 873-880.

[8] M. S. Vilela, E. G. Silva, A. H. Batista, V. J. Farias "A Boost PWM Soft Switching Converter wit Low Switch Voltage and Current Stresses". IEEJ-IPEC'95, vol.3, pp. 1723-1728.

[9] M. S. Vilela, E. G. Silva, V. J. Farias "A Buck PWM Soft-Switching Converter Using a Single Active Switch" IEEJ-IPEC'95, vol.2, pp.956-961.

[10] L. C. de Freitas, N. P. Filho and V. J. Farias, "A Novel Family of DC-DC PWM Converters Using the Self-Resonant Principle", IEEE PESC'94, 1385-1391.

\section{Biographies}

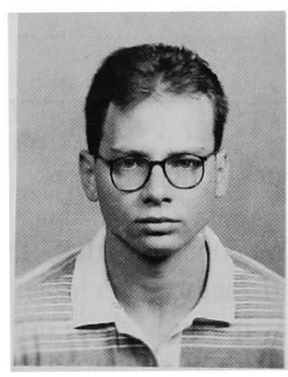

Lúcio dos Reis Barbosa $\mathrm{He}$ was born in Patos de Minas/MG-Brazil on January 19,1969 . He received the B.S. and the M.S. degrees in Electrical Engineering from Federal University of Uberlândia, Brazil, in 1993 and 1996, respectively. Presently he is working toward his $\mathrm{Ph} . \mathrm{D}$. thesis at Federal University of Uberlândia, Brazil. His research interest area is Power Electronics in general, specially Soft- Switching Converters and highfrequency power conversion

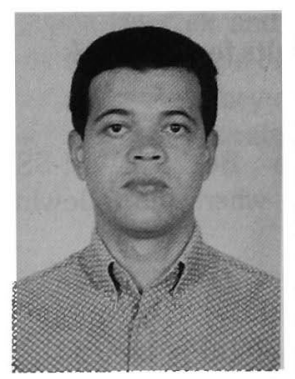

Ernane Antônio Alves Coelho was born in Brazil on July 27, 1962. He received the B.S. degree in Electrical Engineering from Federal University of Minas Gerais, Brazil, in 1987, and M.S. degree in Electrical Engineering from Federal University of Santa Catarina, Brazil, in 1989. Since January 1990, he has been a Member of Research Staff at Power Electronics Research Group of the Federal University of Uberlândia. He is currently working for $\mathrm{Ph} . \mathrm{D}$ degree in Electrical Engineering Research and Development Center of the Federal University of Minas Gerais, Brazil.

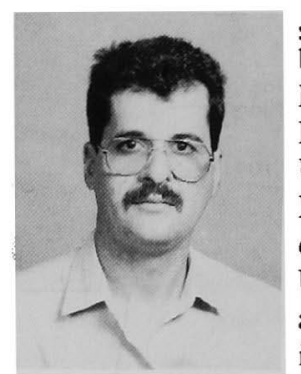

João Batista Vieira Júnior was born in Brazil on March 23, 1955. $\mathrm{He}$ received the B.S. degree in Electrical Engineering from Uberlandia Federal University, Brazil, and the M. S. and Ph.D. degrees from Santa Catarina Federal University, Brazil, in 1980, 1984 and 1991, respectively. Presently he is a professor of the Electrical Engineering department of the Federal University of Uberlândia, Brazil. He has published around 60 papers. His research interest areas include high-frequency power conversion, modeling and control of converters, power factor correction circuits.

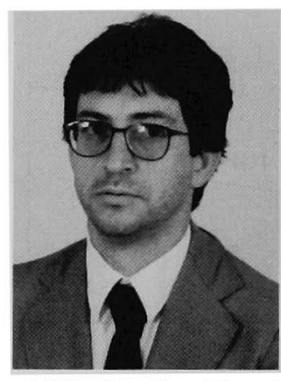

Luiz Carlos de Freitas was born in Brazil on April 1, 1952. He received the B.S. degree in Electrical Engineering from Uberlândia Federal University, Brazil in 1975 and M. S. and Ph.D. degrees from Federal University of Santa Catarina, Brazil, in 1985 and 1992 respectively. Presently he is a professor of the Federal University of Uberlândia, Brazil. He has published around 50 papers and he has two Brazilian patents pending. His research interests include high frequency power conversion modeling and control of converters, power factor correction circuits.

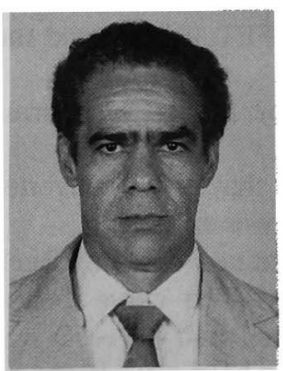

Valdeir José Farias was born in Brazil on November 18, 1947. He received B.S. degree in Electrical Engineering from Uberlândia Federal University, the M. S. degree in Power Electronics from Minas Gerais Federal University and the $\mathrm{Ph} . \mathrm{D}$. degree from Campinas State University in 1975, 1981 and 1989 respectively. He has been a professor at Uberlândia Federal University since 1976. His interesting area is Power Electronics in general. He has published around 50 papers. 